\title{
OBLIGATORY CSR VIA SOCIAL ENTERPRISE CORPORATE BUSINESS ENTITIES
}

\author{
SHAHRIL NIZAM M. ${ }^{\mathbf{1}}$, SYARIZAL A R ${ }^{\mathbf{2}}$, HARTINIE ABD AZIZ ${ }^{\mathbf{2}}$ \\ ${ }^{1}$ Faculty of Entrepreneurship \& Business, University Malaysia Kelantan , Malaysia \\ shahrilnizam@umk.edu.my* (Mohd Shahril Nizam Bin Md Radzi) syarizal.a.r@umk.edu.my (Syarizal Bin Abd Rahim) \\ ${ }^{2}$ Faculty of Law and International Relations, Universiti Sultan Zainal Abidin 21300 Terengganu, Malaysia \\ hartinieabdaziz@unisza.edu.my (Hartinie Abd Aziz)
}

\begin{abstract}
Corporate Social Responsibility (CSR) is primarily a philanthropic concept. The underlying principle that CSR is merely a business voluntary endeavor has become the main problem in the implementation of CSR. One of the developments of CSR enforcement is through the Corporate Code of Conduct $(\mathrm{CoC})$ which is a standard procedure in a company conducting its business activities on the basis of economic, legal and ethical factors. Recently, there are a new business entities known as Low Profit Limited Liability Company (L3C), Benefit Corporation (B Corps), and Community Interest Company (CIC) introduced in the UK as a new vehicle to promote social well-being through business activities, which is believed to be more effective than corporate social responsibility, whereby these new business entities enforce CSR as an obligatory obligation rather than a voluntary act. Main purpose of this article is to examine legal jurisprudence behind establishment of these business entities. This research adopted the doctrinal legal research which focus on review of the regulation and policy contained in primary sources such as, case law, and statutory provisions. Reference will also be made to secondary sources such as textbook, journal articles, report, seminar papers, as well as data from official website.
\end{abstract}

Keywords - CSR, Corporation, Social Enterprise

Article Received: 18 October 2020, Revised: 3 November 2020, Accepted: 24 December 2020

\section{Introduction}

Traditionally, the concept of corporate law only focuses on the rights and interest of shareholders that need to be protected. This is because, from corporate law's perspective, corporations exist resulting from the contractual relationship between shareholders thereby the main objective of corporate law is to provide a legal framework to maximize shareholders' profit.

This view becomes a prominent principle in evolving fiduciary duties upon corporate management in exercising their function as a director (ZA., 2017). Through this principle, the management is entrusted to manage the company with the sole objective of maximizing shareholders' profit.

"Managers are merely agents of stockholders, and thus have no right to spend or give away corporate monies except in the interest of increasing shareholders' wealth... any stockholder is free to use his dividends to support any worthy causes he may choose, but the choice should not be made for him by a president who may not share either his values or properties" (Friedman, 2007)

This has also been recognized by common law court as in ("Great Eastern Railway v Turner ", 1872)

"Directors are the mere trustee or agent of the company, trustee of the company's money and property; agents in the transactions which they enter into on behalf of the company"

Similar to the case of ("Re W \& M Roith Ltd ", 1967), the court held that the role of director was as an agent to the company, therefore he owes a duty to exercise his duty loyally without having bad intention and must perform it with a good faith. Nonetheless, rapid development in industrial revolution gives a significant impact on the environment and the sustainability of the society, while too many pollutions and economic unbalance in the society occurred from industrial operation. 
This phenomenon has triggered the rethinking of corporate law.

\section{Corporate Social Responsibility}

Many scholars proposed that the direction of corporate law should not only focus on shareholder interest but should be extended to none shareholder especially for those who are directly affected from the operation of the company (Hassan, Abd Ghadas, \& Rahman, 2012). Bowen (1953), a pioneer to the idea of corporate social responsibility (CSR), define CSR as an obligation of the business to pursue those policies, to make those decisions or follow those line of action which are desirable in terms of the objective and value of our society". CSR has also been defined as an action taken by businessmen beyond the company's economic objective and interest. (Davis, 1960). In the modern era, such definition is strengthened to include elements of ethic in business activities. For example, World Business Council for Sustainability Development defines CSR as

"continuing commitment by business to behave ethically and contribute to economic development while improving the quality of life of the workforce and their families as well as the local community" (Elkington \& Fennell, 1998), claims that there are three responsibilities for the company in order to ensure economic sustainability and social justice namely as social, economic and environmental quality. All of these obligations are necessary to ensure economic sustainability and social justice. Meanwhile, (Carroll, 1979) identified four responsibilities of companies, which encompass the economic, legal ethic and discretionary expectation from the society.

Acknowledging the important of CSR in sustainable development, several instances of policies have been introduced by countries to encourage private participation in CSR programs. As for examples, the EU Commission has implemented the Code of Conduct which gives freedom to companies to self -regulate in order to achieve their CSR mission (European Commission,
2012). France passed New Economic Regulation in 2001 requiring listed company to disclose the social and environmental impact in their annual report. The same approach has been implemented in Malaysia whereby, all public listed companies have to disclose CSR programs in their annual report (Sarwar \& Azam, 2013). In a nutshell, it could be found that, the concept of CSR is to act as a mechanism to protect the interest of stakeholders who are affected from the operation of the company. This group of people might or might not be directly involved in the corporation. Therefore, through this mechanism, corporations would not be focusing only on the shareholder interest to maximize their profit but also have to take into consideration the stakeholder interest to be part of their legitimacy operation (Alias \& Abdul Ghadas, 2012).

Although the concept of CSR has received a global attention, its existence is still an issue in corporate law. It is well accepted that the goal of corporate governance itself is to maximize the shareholder profits. (Kraakman, 2017). Therefore, any operations or business activities conducted by the corporations have to be in line with its primary objective of establishment. Any attempts to promote stakeholders' interest would oppose shareholders' rights in getting revenue from their investment.

Though there is a finding from the research shows that there is a significant relationship between business performance with CSR programs conducted by the corporation, (Selnes, 1993) most of the companies choose to reserve their obligations in voluntarily basis, as to protect their shareholders' rights. Realizing this problem, an effort has been taken by some jurisdictions such as in United Kingdom and Malaysia to introduce Corporate Code of Conduct as to overcome the issue. This instrument codifies the principles and best practices of good governance, requiring disclosure on CSR programs in the companies' annual report. Through this mechanism, companies are being given flexibility to develop their internal approach to implement CSR programs. 
Nevertheless, despite this action, it's not compulsory for the companies to strictly comply with the code. Consequently, CSR will remain as voluntarily and open to avoidance of obligation from companies on their duties to the communities.

\section{Social Enterprise}

As a respond to the problem mentioned, there is an innovation in corporate law to develop new corporate business entity to serve for business activities and community development. This innovation is called as social enterprise. The concept of social enterprise is always being defined as a hybrid organization operating in a market place but serving for social benefits.

(Dees \& Anderson, 2003) who are social entrepreneurship scholars, give an explanation to this concept. According to them, social enterprise is social purpose venture, such as a hybrid organization mixing not for profit and for profit elements in its operation. This might include homeless shelters that start businesses to train and employ their residents (Dees \& Anderson, 2003). Further, in discussing this new concept, Dee and Anderson had described two main characteristics of social enterprise (Dees \& Anderson, 2003).

1. It's a legally incorporated body whereby the owners have the rights to control over the organization and are entitled for its residual earning.

2. Clearly designed for a hybrid form by making a profit and serve for the community development. Thus, in this context, the purpose of social enterprise is not solely to maximize shareholder profit but it must be coupled with creating value for having a social purpose involving a commitment to create value for a community or society rather than just wealth for the owners or personal satisfaction for customers.

It has also been claimed that a social enterprise has a unique feature whereby the purpose of it creation is for social arm but the ownership and management do not belong to government but community or private sector (Thornton \& Flynn, 2003).

Through social enterprise, many jurisdictions have adopted it into a new business entity as to promote social well-being in their countries. The Low Profit Limited Liability Company (L3C) was introduced in 2008 in United States. As a hybrid organization, $\mathrm{L} 3 \mathrm{C}$ is required to pursue charitable mission and may also distribute its profit to its investors. Benefit Corporation is a social enterprise entity in United States. It was established in 2011. The purpose of its establishment is to facilitate entrepreneurs without disregards to their fiduciary duty for shareholders. Similar to L3C, Benefit Corporation is created by a state, whereby the director is on duty to ensure that the whole operation of the company will consider the other stakeholders' interest. Another example of social enterprise entity is Community Interest Company. It is a private company introduced by the government through Community Interest Company Act 2005 in United Kingdom. Although, Community Interest Company is a private company, its operation is subjected to the state regulations. Failure to comply with such regulation will make the organization cease to be recognized as a social enterprise.

\section{Jurisprudential Theories}

Theoretically it could be suggested that, an establishment of all of those entities as a social enterprise business vehicle is driven by Concession Theory of Corporate Personality. Similar to the other corporate personality theories such as Purpose, Aggregate and Fiction, scholars in Concession Theory also believe that a corporation is an artificial person. This theory also believes that the state as a legal source for it establishment (Ghadas, 2007). In contrast with aggregate theory which has been used to justify conventional corporation and private contract between shareholders, Concession Theory has a state intervention by focusing on the state jurisdiction to design and confer corporate personality to any entity with a specific purpose. Thus, based on this theory, the state has a right to confer rights and 
liabilities for any artificial persons as it wishes to meet the purpose of their establishment (Hassan et al., 2012).

Evidently, the Purpose Theory of corporate personality had been used by the court to justify it relevancy. The House of Lord in ("Taff Vale Rly Co $v$ Amalgamated Society of Rly Servants," 1901) unanimously agreed and held that the requirement to impose a new levy on members of trade union for a political purpose was contrary to the main objective or purpose of the incorporated organization. Lord Macnaghten in his obiter held that :

" it is a broad and general principle that companies incorporated by statue for special purpose and societies, whether incorporated or not , which owe their constitution and their status to Act of Parliament, having their objects and powers defined thereby, cannot apply their funds to any purpose foreign to the purpose for which they were established, or embark on any undertaking in which they were not intended by Parliament to be concerned

In United States, an application of concession theory, can be traced from in Trusteee of Darmouth College v Woods ; Justice Marchall stated;

"A corporation is an artificial being, invisible, intangible and existing only in contemplation of law. Being mere creature of law, its possess only those properties which the charter of its creations confer upon it, either expressly or as incidential to its very existence. These are such as supposed best calculated to effect the object for which it was created .... The object for which a corporation is created are universally such as the government wishes to promote..."

The judgment in an Amalgamated Society's case and Trustee of ("Dartmouth College v. Woodward, 17 U.S. (4 Wheat.) 51,")are very significant to show the power of parliament to recognise any entity as a corporate body for any specific purpose. Therefore, in different with conventional corporation, the state has a power to create any entities which would have multi fiduciaries in their operation. Through this new direction in corporate law, social enterprise entities will act as a hybrid organization in achieving their dual mission. Thus, management in social enterprise entities is required to execute CSR as a mandatory but does not disregard the shareholder interest. Hence, in relation to social enterprise entities above, states have created a special corporate organization to become a new business vehicle in order to facilitate social enterprise industry in their respective jurisdiction. Through a Concession Theory of Corporate Personality, the state also has developed a new framework of corporate governance in order to distinguish itself from the conventional corporation. Accordingly, it might prevent any conflict of interest with shareholders, when the company intends to prioritize social development rather than to maximize shareholders' profit.

\section{Conclusion}

The concept of CSR, as implemented in conventional corporation has triggered conflict of interest between two primacies in corporate governance. Nevertheless, in conventional corporation, priority should be given to shareholders' benefit to respect the nature of its establishment. Through a new innovation in entrepreneurship, commercial activities could also be used as a tool for community development. Although CSR and social enterprise share similar interest, the priority in CIC as social enterprise organizations for that interest could be efficient through obligatory CSR as embodied in its governance.

\section{REFERENCES}

[1] Alias, S. A., \& Abdul Ghadas, Z. (2012). Inequality of bargaining power and the doctrine of unconscionability: Towards substantive fairness in commercial contracts. Australian Journal of Basic and Applied Sciences, 6(11), 331-341.

[2] Carroll, A. B. (1979). A three-dimensional conceptual model of corporate 
performance. Academy of management review, 4(4), 497-505. https://doi.org/10.5465/amr.1979.4498296

[3] Dartmouth College v. Woodward, 17 U.S. (4 Wheat.) 51.

[4] Davis, K. (1960). Can business afford to ignore social responsibilities? California management review, 2(3), 70-76. https://doi.org/10.2307\%2F41166246

[5] Dees, J. G., \& Anderson, B. B. (2003). Forprofit social ventures. International Journal of Entrepreneurship Education, 2(1), 1-26.

[6] Elkington, J., \& Fennell, S. (1998). Partners for sustainability. Greener Management International, 48-48.

[7] Friedman, M. (2007). The social responsibility of business is to increase its profits Corporate ethics and corporate governance (pp. 173-178): Springer.

[8] Ghadas, Z. A. A. (2007). Real or ArtificialJurisprudential Theories on Corporate Personality. US-China Law Review, 4, 6.

[9] Great Eastern Railway v Turner (1872). LR 8 Ch App 149

[10] Hassan, H., Abd Ghadas, Z. A., \& Rahman, N. A. (2012). The Myth of Corporate Personality': A comparative Legal Analysis of the Doctrine of Corporate Personality of Malaysian and Islamic Laws. Australian Journal of Basic and Applied Sciences, 6(11), 191-198.

[11] Kraakman, R., \& Hansmann, H. (2017). The end of history for corporate law. In Corporate Governance (pp. 49-78). Gower.

[12] Re W \& M Roith Ltd (1967). 1 WLR 432

[13] Sarwar, A., \& Azam, F. (2013). Corporate Social Responsibility in Malaysia: The Role of Corporate Sector in Supporting the Community and the Environment. Research Journal of Commerce \& Behavioural Science, 2(03), 54-59.

[14] Selnes, F. (1993). An examination of the effect of product performance on brand reputation, satisfaction and loyalty. European Journal of marketing, 27(9), 19-
35. https://doi.org/10.1108/030905693100431 79

[15] Taff Vale Rly Co v Amalgamated Society of Rly Servants. (1901). AC 426, HL

[16] Thornton, P. H., \& Flynn, K. H. (2003). Entrepreneurship, networks, and geographies Handbook of entrepreneurship research (pp. 401-433): Springer.

[17] ZA., H. H. a. A. G. (2017). Duties Of Nominee Directors; Special Reference To Confidentiality Of Company's Information, JSSH 25 (S) Mar. pp 143-154 